Utah State University

DigitalCommons@USU

Behavioral Education for Human, Animal,

Vegetation, and Ecosystem Management

(BEHAVE)

1990

\title{
Conditioned Flavor Aversion: A Mechanism for Goats to Avoid Condensed Tannins in Blackbrush
}

\author{
Frederick D. Provenza \\ Utah State University \\ Elizabeth A. Burritt \\ Utah State University \\ T. P. Clausen \\ University of Alaska - Fairbanks \\ J. P. Bryant \\ University of Alaska - Fairbanks \\ P. B. Reichardt \\ University of Alaska - Fairbanks \\ Roberto A. Distel \\ Utah State University \\ Follow this and additional works at: https://digitalcommons.usu.edu/behave \\ Part of the Animal Sciences Commons
}

\section{Recommended Citation}

F. D. Provenza; E. A. Burritt; T. P. Clausen; J. P. Bryant; P. B. Reichardt; R. A. Distel. The American Naturalist, Vol. 136, No.6 (Dec., 1990), 810-828.

This Article is brought to you for free and open access by the Conferences and Events at DigitalCommons@USU. It has been accepted for inclusion in Behavioral Education for Human, Animal, Vegetation, and Ecosystem Management (BEHAVE) by an authorized administrator of DigitalCommons@USU. For more information, please contact digitalcommons@usu.edu. 


\title{
CONDITIONED FLAVOR AVERSION: A MECHANISM FOR GOATS TO AVOID CONDENSED TANNINS IN BLACKBRUSH
}

\author{
F. D. Provenza, ${ }^{*}$ E. A. Burritt,$*$ T. P. Clausen,$\dagger$ J. P. Bryant, $\neq$ \\ P. B. Reichardt $\uparrow$ and R. A. Distel* \\ *Range Science Department, Utah State University, Logan, Utah 84322-5230; †Department of \\ Chemistry, University of Alaska, Fairbanks, Alaska 99775-0520; $¥$ Institute of Arctic Biology, \\ University of Alaska, Fairbanks, Alaska 99775-0180
}

Submitted February 2, 1989; Accepted August 1, 1989

There is growing evidence that different species of mammalian herbivores are not equally vulnerable to tannins in plants and that types of tannins differ in their effects. Tannins in some plant species are presumed to affect nutrition adversely (see, e.g., McLeod 1974; Rhoades 1979; Swain 1979; Zucker 1983; Kumar and Singh 1984; Robbins et al. 1987a), and diet selection by some mammalian herbivores is inversely correlated with tannins (Provenza and Malechek 1984; Cooper and Owen-Smith 1985; Cooper et al. 1988). Conversely, certain tannin-producing plant species are nutritious (see, e.g., McLeod 1974; Bernays and Woodhead 1982; Robbins et al. 1987b; Nunez-Hernandez et al. 1989) and are readily ingested by mammalian herbivores (see, e.g., Shepherd 1971; Kufeld 1973; Kufeld et al. 1973; Riggs et al. 1988). The factors underlying these differences are poorly understood (review in Bernays et al. 1989).

In this article, we argue that some condensed tannins (CTs) are indeed feeding deterrents to mammalian herbivores, and we present experimental evidence that goats avoid the current season's twigs of blackbrush (Coleogyne ramosissima Roseaceae), because they contain such tannins. Moreover, our data show that goats learn to avoid blackbrush twigs containing high levels of CTs, apparently by associating the flavor of blackbrush twigs with aversive postingestive consequences. We argue that these adverse consequences are not related to digestion inhibition. We also argue that differences in CT structure and the manner in which CTs are bound with other cell constituents preclude generalizations about the role of CTs in diet selection and the nutrition of mammalian herbivores.

We first present experimental evidence that goats learn through aversive postingestive consequences to avoid the current season's blackbrush twigs, which are high in CTs. We then show that goats learn to avoid otherwise palatable novel foods to which we have added purified CTs or lithium chloride. Finally, we develop hypotheses concerning the mechanisms that underlie the interaction between mammalian herbivores and plants that contain CTs. 
TABLE 1

\begin{tabular}{|c|c|c|c|c|}
\hline \multirow[b]{2}{*}{ Day } & \multicolumn{2}{|c|}{ CaLfmanNa } & \multicolumn{2}{|c|}{ Older Growth } \\
\hline & Offered & Ingested & Offered & Ingested \\
\hline 1 & 200 & 193 & 300 & 278 \\
\hline 2 & 150 & 145 & 500 & 478 \\
\hline 3 & 150 & 150 & 550 & 498 \\
\hline 4 & 150 & 150 & 650 & 623 \\
\hline 5 & 150 & 150 & 750 & 690 \\
\hline
\end{tabular}

EXPERIMENTS WITH GOATS AND BLACKBRUSH

Blackbrush grows in dense stands on infertile soils in the transition zone between the cold and hot deserts of the southwestern United States (Bowns and West 1976). It grows slowly in the absence of browsing, but removal of terminal buds by herbivores during the winter, when blackbrush is dormant, stimulates twig growth during the spring (Bowns and West 1976; Provenza et al. 1983a, $1983 \mathrm{~b}$ ). The following winter, the current season's growth (CSG) of twigs and leaves on browsed plants is higher in nitrogen $(1.04 \%$ vs. $0.74 \%)$ and more digestible in vitro in goat rumen fluid (48\% vs. $38 \%$ ) than are twigs and leaves from older growth (OG) of unbrowsed plants (Provenza et al. 1983a). However, goats prefer to eat OG of previously unbrowsed plants when allowed to choose between CSG and OG (Provenza and Malechek 1984, 1986).

\section{Experiment 1}

Goats from shrub-dominated ranges in Texas strongly avoid blackbrush CSG when introduced to blackbrush-dominated ranges in Utah (Provenza and Malechek 1984, 1986). However, we do not know whether goats avoid blackbrush CSG because of its (1) flavor, (2) aversive postingestive consequences, or (3) similarity to twigs in Texas that goats learn to avoid (Provenza and Malechek 1986; Provenza et al. 1988, 1990). The objective of the first experiment was to determine whether or not blackbrush CSG was an acceptable food to goats naive to shrubs including blackbrush, and, if not, whether goats avoided blackbrush CSG because of its flavor or because of its aversive postingestive consequences.

Methods. - The experiment involved 11 yearling goats (average body weight about $30 \mathrm{~kg}$ ) that were naive to blackbrush but had foraged on grass pasture and alfalfa hay and pellets. The goats were penned individually. During the first $5 \mathrm{~d}$, goats were offered calfmanna, a concentrate-based pellet high in protein $(26 \%)$ and energy, and OG blackbrush (table 1). OG blackbrush was harvested daily and chopped into segments $1-3 \mathrm{~cm}$ in length. Our objective was to familiarize the goats with OG and to determine how much OG they would eat. During the next $5 \mathrm{~d}$, goats received $150 \mathrm{~g}$ of calfmanna daily and were allowed to choose between CSG and OG offered in separate food boxes. The CSG and OG were 

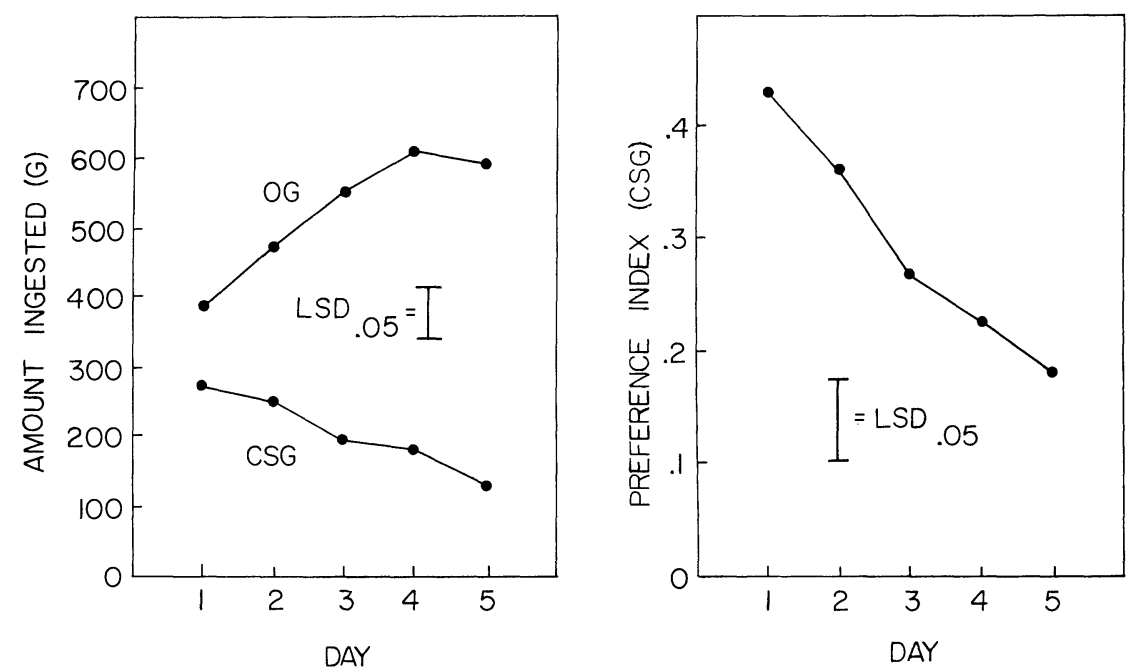

FIG. 1.- Voluntary intake of the current season's growth (CSG) and older growth (OG) of blackbrush and preference for CSG by goats during five consecutive days. The preference index (PI) is calculated as the amount of CSG ingested divided by the total amount of CSG and OG ingested. A PI of 0.5 indicates equal preference for CSG and OG; the PI for OG is calculated as 1 minus the PI for CSG. The standard error of a mean for voluntary intake is $25 \mathrm{~g}$ and for a preference index is 0.03 . Vertical bar, $\mathrm{LSD}_{.05}$, the least significant difference at $P=.05$.

hand-harvested daily and chopped into segments $1-3 \mathrm{~cm}$ in length. Goats had access ad lib. to CSG and OG from about 0900 hours to 1700 hours daily. The statistical design for the ANOVA was a randomized block with food (CSG vs. OG) as the main effect and individual goats $(n=11)$ as blocks. The experiment was repeated on several consecutive days $(n=5)$, which required use of a repeated-measures analysis (Winer 1971).

Results.-After initially sampling CSG and OG, all goats fed actively on CSG for 4 to $5 \mathrm{~h}$ on day 1 . As the day progressed, consumption of CSG declined, and consumption of OG increased. Goats ate somewhat less CSG than OG (271 vs. $387 \mathrm{~g} ; P<.05)$ by the end of day 1 but showed no difference $(P>.05)$ in their preference (i.e., grams of CSG ingested divided by the grams of CSG + OG ingested) for CSG or OG (0.43 vs. 0.57). Throughout the remainder of the trial, consumption of CSG by goats declined and consumption of OG increased (fig. 1). By day 5, goats ingested considerably less CSG than OG (125 vs. $590 \mathrm{~g}$ ) and strongly preferred OG to CSG (0.82 vs. 0.18$)$. Goats generally ingested all of the calfmanna.

Intake of and preference for CSG varied among goats $(P<.05)$. Nine goats decreased intake of CSG markedly on days 2 and 3, but two goats did not reduce intake until days 4 and 5. These two goats ingested large amounts of CSG compared with the other goats ( $376 \mathrm{vs} .166 \mathrm{~g} / \mathrm{d}$ ) and showed a much higher preference for CSG throughout the experiment $(0.51$ vs. 0.25$)$. The goats were twins that 
may possess physiological mechanism(s) enabling them to tolerate more CSG. If such a mechanism(s) existed, it would provide a basis for either natural or artificial selection (Dove 1935; Freeland and Janzen 1974).

\section{Experiment 2}

Tannins occur commonly in both woody (about 80\%) and herbaceous (about $15 \%$ ) dicotyledonous plant species (Bate-Smith and Metcalf 1957; Rhoades and Cates 1976) and have been a topic of great interest to ecologists studying plantherbivore interactions. Theories involving plant antiherbivore chemistry consider CTs the prototypic quantitative plant defense, presumably because CTs deter feeding by herbivores by reducing the digestibility of plant tissues (see, e.g., Feeny 1976; Rhoades and Cates 1976; Rhoades 1979; Swain 1979; Bryant et al. 1983; Zucker 1983; Coley et al. 1985). However, evidence documenting the deterrent effects of tannins on the voluntary intake of foods by mammalian herbivores is correlative (Wilkins et al. 1953; Donnelly 1954; Hawkins 1955; Driedger and Hatfield 1972; Jones et al. 1976; Provenza and Malechek 1984, 1986; Cooper and Owen-Smith 1985; Cooper et al. 1988), and the purported adverse effects of tannins on dry-matter digestion in mammals have recently been questioned (Robbins et al. 1987b; review in Bernays et al. 1989). To establish deterrence of a specific secondary metabolite, that metabolite must be incorporated in an artificial diet (Reichardt et al. 1984, 1987). Thus, the second experiment sought to determine whether purified CTs from blackbrush CSG deterred feeding by goats, and, if so, whether goats avoided purified CTs because of flavor or because of aversive postingestive consequences.

Methods.-The 4-yr-old goats ( $n=12$; average body weight about $60 \mathrm{~kg}$ ) had foraged on rangeland dominated by blackbrush for about 2 mo before this experiment, and their diet probably contained more than $85 \%$ blackbrush (Provenza and Malechek 1984, 1986). During the first $5 \mathrm{~d}$ of the experiment, individually penned goats were offered older-growth blackbrush pellets (OGP) ad lib. During the next $5 \mathrm{~d}$ of the experiment, goats could choose between OGP and OGP to which purified CTs had been added (OGPT). The CTs, extracted from blackbrush CSG and purified according to the method of Hagerman and Butler (1980), were added to OGP in the concentration equal to their isolated yield from CSG $(2.5 \%)$. The powdery CTs were applied as a coating to the outside of OGP moistened with water, because CTs are found primarily in the bark of blackbrush CSG (F. D. Provenza, unpublished data). The preference trials lasted for $30 \mathrm{~min}$ per day for $5 \mathrm{~d}$ and were conducted at about 0700 hours following an overnight fast. During daily trials, each goat was offered $200 \mathrm{~g}$ of OG and $200 \mathrm{~g}$ of OGPT. Both food boxes were removed if a goat ingested all of either OGP or OGPT before $30 \mathrm{~min}$. Goats had free access to OGP until 1700 hours following daily trials. The statistical design (Winer 1971) for the repeated-measures ( $n=5$ consecutive days) ANOVA was a randomized block with food (OGP vs. OGPT) as the main effect and individual goats $(n=12)$ as blocks.

Results.-Purified CTs from blackbrush CSG deterred feeding by goats. Goats consumed less OGPT than OGP (26\% vs. $51 \% ; P=.019)$ during the 5 -d trial. An interaction was suggested $(P=.069)$ between food (OGPT vs. OGP) and day 


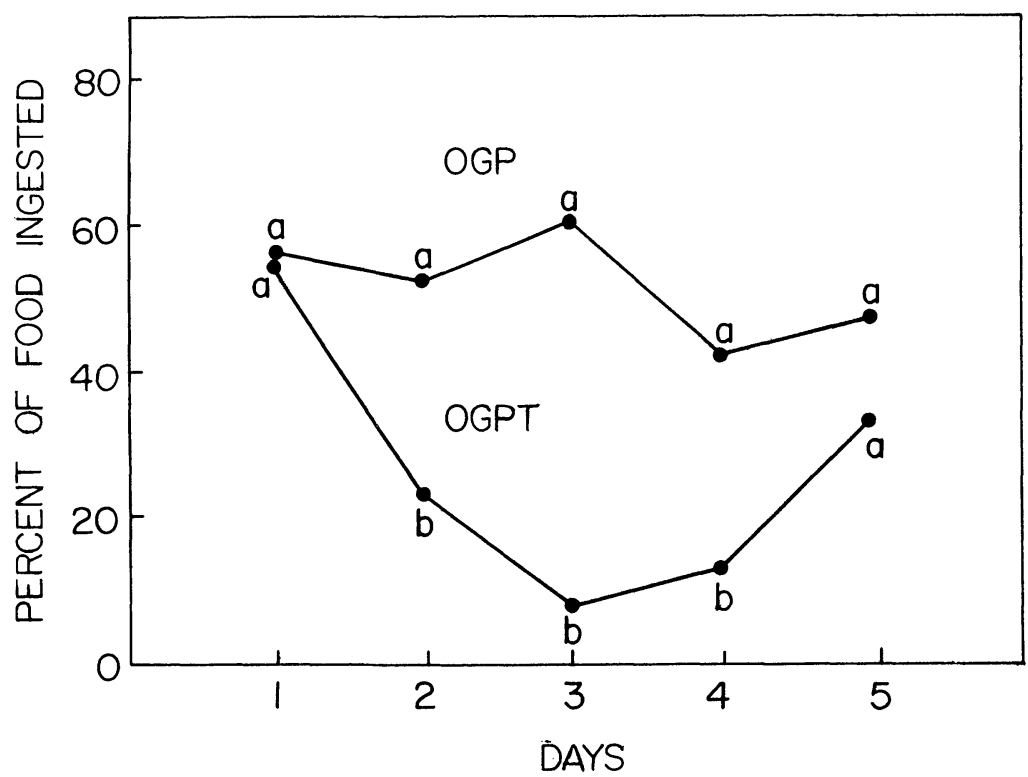

Fig. 2.-Percentage of older-growth blackbrush pellets (OGP) and older-growth blackbrush pellets coated with purified condensed tannins (OGPT) ingested by goats during 30 $\mathrm{min} / \mathrm{d}$ for five consecutive days. Means with different letters for each day are different; least significant difference (at $P=.05$ ). Standard error of a mean, $8 \%$.

of trial. Goats ate equal percentages of OGPT and OGP on day 1 , but consumption of OGPT declined sharply on days 2 through 4 . Intake of OGPT increased on day 5 (fig. 2).

Discussion.-Goats initially consumed similar amounts of CSG and OG (fig. 1) and OGP and OGPT (fig. 2), which suggests that neither the flavor of CSG nor that of purified CTs from blackbrush CSG were inherently offensive to goats. Likewise, the low preference of goats for blackbrush CSG is apparently not related to astringency, because purified CTs from blackbrush CSG are less astringent than those from bitterbrush CSG (Clausen et al. 1990), a food palatable to many mammalian herbivores (see, e.g., Shepherd 1971; Kufeld 1973; Kufeld et al. 1973; Riggs et al. 1988). Rather, consumption of CSG and OGPT declined after day 1, suggesting that postingestive distress began sometime during the first day of the trial. Goats associated this distress with CSG and OGPT, which were novel foods at the beginning of the feeding trials, and this association resulted in a conditioned flavor aversion (CFA) for blackbrush CSG and OGPT.

Intake of blackbrush CSG by goats has been shown to be inversely correlated with CTs (Provenza and Malechek 1983, 1984). Here we have demonstrated that the avoidance of CSG by goats was caused by CTs. However, the goats' intake of OGPT increased on day 5 of experiment 2, while their intake of CSG declined steadily throughout experiment 1 . We offer three explanations for this variation in the response of goats to blackbrush OGPT and CSG. 
The most likely explanation for the difference is that the amount of CT applied to OGP was much less than that found in CSG. The isolated yield of CTs $(2.5 \%)$ was only $10 \%$ of that contained in the aqueous methanol extractables $(25 \%)$, which are almost exclusively CTs (Clausen et al. 1990). Thus, isolated yields are a poor measure of CT concentration in blackbrush CSG because most of the lower-molecular-weight CTs, and a portion of the larger CTs, are lost during isolation and purification. Although it is possible that other secondary metabolites in blackbrush CSG may act synergistically (Berenbaum 1985; Kubo and Hanke 1985) to strengthen the aversion of goats to CTs, we found no evidence that this was the case. The only other major secondary metabolite, found in the ether extract, was ursolic acid, which is a triterpene carboxylic acid. Ursolic acid was only mildly deterrent to goats fed OGP (PI $=0.39 \pm 0.09$; preference index \pm 95\% confidence interval), whereas compounds extractable in aqueous methanol were highly deterrent to goats fed OGP $(\mathrm{PI}=0.18 \pm 0.09)$. When goats were fed OGP containing both ether- and methanol-extractable compounds, their preference for OGP increased numerically (PI $=0.23 \pm 0.09$ ), though not significantly $(P>.05)$. Collectively, these data suggest that the response of goats was caused by differences in the concentration of CTs between OGPT and CSG, not by synergisms between different compounds in blackbrush CSG.

Another explanation for the increased intake of OGPT on day 5 is that goats may possess mechanisms that enable them to adapt to purified CTs. For example, the size of goat parotid salivary glands and their production of proline-rich proteins may increase in response to diets high in tannins, as demonstrated for rats (Mehansho et al. 1983, 1987). Proline-rich salivary proteins apparently are a primary defense of rats (Mehansho et al. 1983, 1987; Butler et al. 1986) and may serve the same function for herbivores such as goats (Robbins et al. 1987b; Austin et al. 1989) by forming tannin-protein complexes that presumably pass intact through the gastrointestinal tract. Alternatively, sheep may adapt to diets high in CTs (Barry 1985; Lowther and Barry 1985) by unknown mechanisms that apparently do not involve tannin-binding proteins (Austin et al. 1989).

Finally, the increased intake of OGPT on day 5 may have occurred because goats were sampling OGPT to determine, from postingestive consequences, how much they could safely ingest. Herbivores such as goats have a strong propensity to sample foods, even those that cause internal malaise, and they apparently are able to determine the amount of such foods that they can ingest without suffering distress (reviews in Provenza and Balph 1987, 1988, 1990). For example, sheep sample foods that contain lithium chloride and apparently limit their intake just enough to prevent gastrointestinal distress (Thorhallsdottir et al. 1987; Burritt and Provenza 1989; du Toit et al. 1990).

\section{Experiment 3}

The last experiment evaluated the ability of goats to establish CFAs under conditions similar to those in experiments 1 and 2 . In experiment 3 we used an otherwise nutritious food (alfalfa pellets [AP]) treated with lithium chloride ( $\mathrm{LiCl})$. $\mathrm{LiCl}$ has been used widely in psychological studies to induce CFAs (see Braveman and Bronstein 1985). Lithium drugs are readily absorbed from the gastroin- 


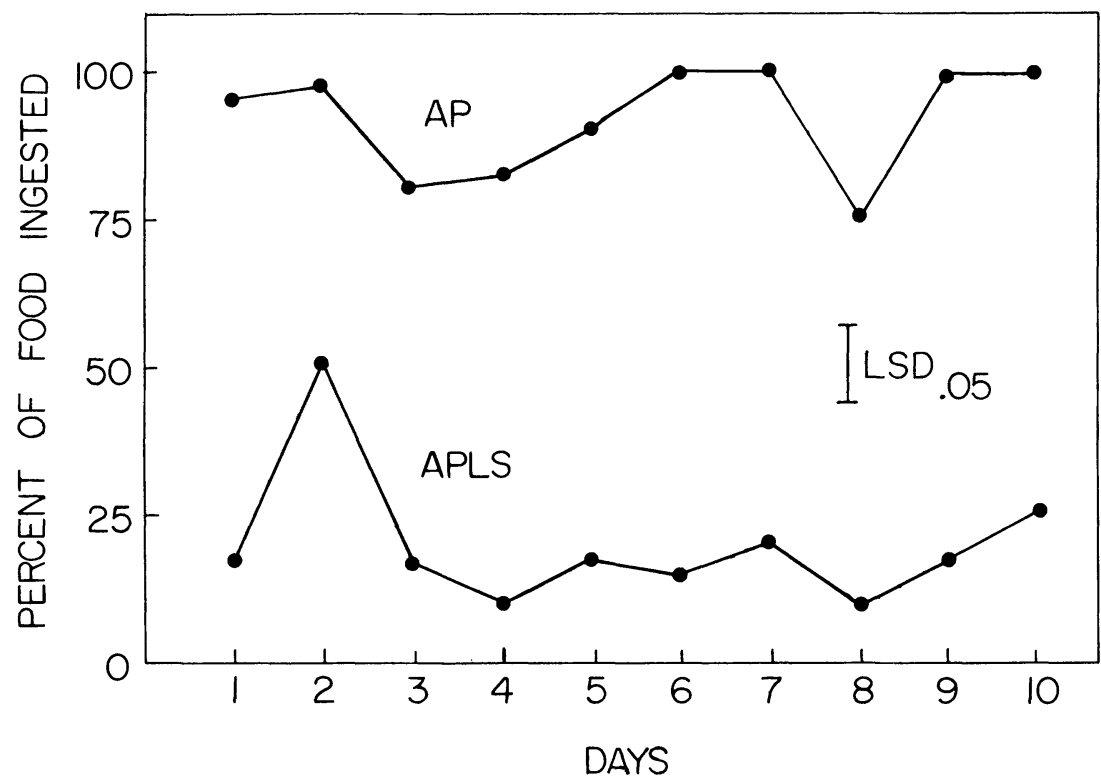

FIG. 3.-Percentage of alfalfa pellets (AP) and alfalfa pellets that contained $2 \% \mathrm{LiCl}$ and $5 \%$ sucrose (APLS) ingested by goats during $1 \mathrm{~h} / \mathrm{d}$ for a $10-\mathrm{d}$ trial. Standard error of a mean, $5 \%$. Vertical bar, $\mathrm{LSD}_{.05}$, the least significant difference at $P=.05$.

testinal tract into the blood and can be detected in the urine of sheep within $2 \mathrm{~h}$ of oral administration (Harrison et al. 1963). In humans, lithium causes nausea, diarrhea, and vomiting (Prien et al. 1971), but no overt signs of distress are apparent in sheep (Thorhallsdottir et al. 1987; du Toit et al. 1990).

Methods.-Ten 4-yr-old goats (average body weight about $60 \mathrm{~kg}$ ) could choose between a basal diet of AP and AP containing $2 \% \mathrm{LiCl}$ and $5 \%$ sucrose (APLS). The preference trials lasted $1 \mathrm{~h}$ per day for $10 \mathrm{~d}$ and were conducted at about 0800 hours following an overnight fast. During daily trials, each goat was offered half of its daily ad lib. intake as AP and half as APLS. Goats were offered AP ad lib. for $14 \mathrm{~d}$ before the start of this experiment. Goats were given free access to AP until 1700 hours following daily trials. The statistical design (Winer 1971) for the repeated-measures ( $n=10$ consecutive days) ANOVA was a randomized block with food (AP vs. APLS) as the main effect and individual goats $(n=10)$ as blocks.

Results.-Goats sampled APLS on day 1 and increased intake on day 2 (fig. 3). They decreased consumption of APLS on days 3 and 4, and their intake of APLS was generally stable for the remainder of the trial.

Discussion.-Food neophobia is manifested when animals sample a novel food cautiously or when they associate postingestive distress with a novel food (Provenza and Balph 1988). Mammalian herbivores apparently ingest small amounts of novel foods initially, and gradually increase intake if the postingestive consequences are not aversive (Freeland and Janzen 1974; Rozin 1976; Chapple 
and Lynch 1986; Chapple et al. 1987a, 1987b; Thorhallsdottir et al. 1987; Burritt and Provenza 1989). In addition, animals offered a meal of several familiar foods and a novel food associate aversive postingestive consequences with, and subsequently avoid, the novel food (Burritt and Provenza 1990), even when the familiar food contains the poison (Camazine 1983; Burritt and Provenza 1989). In experiments 1, 2, and 3, goats could choose between a familiar and a novel food. Goats always associated illness with, and subsequently avoided, the novel food.

Although our experiments give no indication of cautious sampling of OGPT by goats and little indication that goats sampled CSG cautiously, goats did sample APLS cautiously. Healthy animals, normally suspicious of novel foods, become eager to feed on such items when they experience nutritional deficiencies (Garcia et al. 1977), and inadequate nutrition may have caused goats to ingest large amounts of OGPT on day 1 of experiment 2 . Goats consumed only $592 \mathrm{~g}$ of OGP per goat per day during experiment 2. The low intake, and the fact that OG blackbrush is low in nitrogen and poorly digestible (Provenza et al. 1983a), suggests that goats were not ingesting enough food to meet their daily nutritional requirements (National Research Council 1981). Their voluntary intake of alfalfa pellets in the $3 \mathrm{~d}$ immediately following the experiment $(887 \mathrm{~g} / \mathrm{goat} / \mathrm{d})$ was $50 \%$ higher than their voluntary intake of blackbrush pellets $(592 \mathrm{~g} / \mathrm{goat} / \mathrm{d})$ during the trial. Nutrition was adequate in experiments 1 and 3 (National Research Council 1981).

\section{DEVELOPING WORKING HYPOTHESES}

\section{Learning by Consequences}

Plant metabolites such as CTs deter herbivores from feeding on woody plant tissues, presumably because they interfere with digestive or metabolic processes. Thus, natural selection should favor feeding behavior that minimizes ingestion of CTs (Freeland and Janzen 1974; Rhoades 1979), and herbivores must either instinctively recognize or learn to avoid these metabolites (Chapman and Blaney 1979; Provenza and Balph 1990). Instinctive responses presumably involve recognition of the secondary metabolite, and learned responses apparently involve association of the flavor of the plant tissue with aversive postingestive consequences. Browsers such as goats supposedly instinctively recognize and avoid plant tissues that contain CTs (see, e.g., Rhoades 1979; Cooper and Owen-Smith 1985; Cooper et al. 1988), presumably because goats are browsers and most woody plants contain CTs (about 80\%; Bate-Smith and Metcalf 1957; Rhoades and Cates 1976). However, many plants high in CTs are highly palatable (see, e.g., Shepherd 1971; Kufeld 1973; Kufeld et al. 1973; Riggs et al. 1988; NunezHernandez et al. 1989), and the diverse array of CT structures (Zucker 1983; Clausen et al. 1990) and food flavors makes it unlikely that goats can instinctively recognize and avoid plants that contain CTs (Provenza et al. 1988; Provenza and Balph 1990). Thus, we argue that goats learn to avoid blackbrush CSG because of internal malaise, not because of the flavor of CTs. Our results support this hypothesis and are consistent with previous studies of CFAs in ruminants (see, 
e.g., Zahorik and Houpt 1977, 1981; Olsen and Ralphs 1986; Burritt and Provenza 1989, 1990; Thorhallsdottir et al. 1990a, 1990b, 1990c) and with our experiment using $\mathrm{LiCl}$ as a cause of postingestive distress in goats.

Learning is important in plant-herbivore interactions (Lindroth 1988; Provenza and Balph 1990; Provenza et al. 1990). CFAs occur with a diverse array of compounds (Riley and Tuck 1985), in species as phylogenetically and ecologically diverse as garter snakes and tiger salamanders; quail, blackbirds, blue jays, and crows; rats, opossums, and mongooses; coyotes and timber wolves; goats, sheep, and cattle; and olive baboons and humans (see reviews in Rozin 1976; Barker et al. 1977; Garcia et al. 1977; Zahorik and Houpt 1977, 1981; Braveman and Bronstein 1985; Provenza et al. 1990). Some argue that the process is similar in all animals (Garcia et al. 1985; Garcia 1989).

CFAs occur when animals learn to avoid a particular food (conditional response) by associating its taste (unconditional stimulus) with aversive postingestive feedback (Garcia and Holder 1985; Garcia et al. 1985; Garcia 1989; Provenza et al. 1990). Negative feedback, presumably caused by any compound that produces nausea, reduces the hedonic value of the food. For example, some animals readily accept sweet tastes and reject bitter ones, which suggests that the tastes are unconditional stimuli signifying nutrients and toxins, respectively (Garcia and Hankins 1975, 1977). However, the hedonic value of these tastes can be reversed by a single pairing of sweet taste with negative gastrointestinal feedback or bitter taste with nutritive feedback (Garcia and Holder 1985). In the case of blackbrush CSG, negative feedback caused by CTs converts a positive unconditional stimulus to a negative one, thus protecting goats from future encounters with CSG. The conditional stimulus (e.g., odor or sight of a particular food) is the signal the animal uses to avoid specific foods that elicit negative feedback. The conditional odor stimulus, the unconditional taste stimulus, and the specific compound that causes aversive feedback need not be and probably rarely are synonymous because several chemical compounds combine to produce a food's characteristic flavor.

CFAs can occur without overt behavioral signs (e.g., emesis, toxicosis, sickness, illness), and, once the flavor has been presented, a delayed nauseous feedback is effective in producing a CFA even if it is presented while the animal is anesthetized (Roll and Smith 1972; Bermudez-Rattoni et al. 1988), while the animal is deeply tranquilized and unresponsive to pinches and probes (Forthman Quick 1984), or when its electrocortical activity is depressed (J. Davis and Bures 1972; Buresova and Bures 1973). Consequently, aversions may be manifested in the absence of any cognitive association or memory of the feedback event, because the critical psychological process is a hedonic shift in the palatability of the taste (Garcia 1989). This shift is caused by a stimulation of the emetic system of the midbrain and brain stem (Garcia 1989), which can be accessed by many means, including but not limited to the cardiovascular system, cerebrospinal fluid, visceral afferent nerves, and second-order gustatory afferents that connect with the nucleus of the solitary tract (Wang 1965; Borison 1986; C. Davis et al. 1986; Grahame-Smith 1986). Feedback mechanisms that operate while an animal sleeps are advantageous because digestion and absorption are slow processes and prolonged rest often follows a meal (Bermudez-Rattoni et al. 1988). 
Receptor systems commonly involved in conditioning are sensitive to the onset, rather than the duration, of stimulation. For example, if the eyes, ears, or nose do not detect stimulation within a few seconds, they will never detect it no matter how long it endures. In fact, receptors become less sensitive to stimulation with duration. However, feedback receptors are apparently more sensitive to duration and (or) accumulation than to the onset of stimulation, because they are detecting thresholds of titers of solutions in body fluids (Borison 1986; C. Davis et al. 1986; Grahame-Smith 1986).

Compounds that are toxic do not necessarily produce CFAs, whereas some nontoxic compounds do produce CFAs (Gamzu et al. 1985; Garcia et al. 1985; Riley and Tuck 1985; Provenza et al. 1988, 1990). Hence, the fact that a compound produces a CFA says very little about the nature of the compound (Gamzu et al. 1985). Presumably, any physiological, emotional, or perceptual event or any physiochemical agent that causes nausea will establish a CFA, even at doses insufficient to produce overt signs of nausea, provided that the event or agent affects the emetic system of the midbrain and brain stem (Wang 1965; Garcia 1989). Drugs such as Nembutal and cyanide do not cause CFAs, apparently because they do not affect the emetic system (Garcia et al. 1985). Likewise, gallamine, which causes neuromuscular blockage, and naloxone, which blocks the action of endogenous opiates on pain, cause rats to form strong place aversions but only weak CFAs (Lett 1985). Allergies, bloating, and lower-intestinal discomfort also do not cause CFAs (Pelchat et al. 1983; Garcia 1989). Conversely, drugs such as $\mathrm{LiCl}$, which cause nausea in mammals (Prien et al. 1971), cause rats to form strong CFAs but only weak place aversions (Lett 1985). Thus, a plant need not be toxic or interfere with digestive processes to avoid being eaten. Rather, the plant need only produce a compound that stimulates the emetic system to produce a CFA.

\section{Goats and Learning}

The fact that purified CTs from blackbrush CSG cause a CFA in goats says nothing about whether or not blackbrush tannins have other aversive effects in goats. Indeed, given that goats forced to ingest CSG during the winter lose less weight than goats that are free to choose either OG or CSG (Provenza and Malechek 1984), one could argue that the only adverse effect of CTs on goats is that they cause a CFA. However, depolymerization of CTs, particularly procyanidins (Hemingway and McGraw 1983), readily occurs under acidic conditions similar to those in portions of the digestive tract of most mammalian herbivores (Butler et al. 1986; Clausen et al. 1990). Hence, some CTs may be toxic (McLeod 1974; Kumar and Singh 1984; Lindroth and Batzli 1984; Mehansho et al. 1985; Butler et al. 1986). We do not know whether CTs from blackbrush depolymerize in the gut or whether they are toxic. If depolymerization is involved, we predict that CT-depolymerization products should be detectable in the blood and urine, as opposed to the feces, of goats. Likewise, we should find evidence of CTs interfering with the functional activity of one or more organs and increased microsomal enzymatic activity in the liver. In addition, hydrolyzable tannins from some plant species cause severe necrosis and ulceration of the epithelium of the esophagus, stomach, intestines, and proximal renal tubules (Dollahite et al. 1962; Pigeon et 
al. 1962; Boyd et al. 1965; McLeod 1974; Mitjavila et al. 1977; Sandusky et al. 1977; Divers et al. 1982; Anderson et al. 1983). Hydrolyzable tannins apparently cause injury to mucosal epithelium, endothelium, and renal tubular epithelium by binding to tannins (Spier et al. 1987). Although hydrolyzable and condensed tannins are structurally different, both kinds of tannins are capable of forming strong complexes with certain types of proteins (Hagerman and Klucher 1986). The CTs in sorghum do not erode the intestinal epithelium (Sell et al. 1985), but we do not know how blackbrush CTs affect the gastrointestinal tract. The effect may depend on CT structure (Zucker 1983; Clausen et al. 1990) and thus may differ for sorghum and blackbrush.

In addition, CTs from blackbrush CSG may reduce protein or dry-matter digestion, and goats may form aversions to foods like CSG that are low in protein and high in CTs. Animals fed a nutrient-deficient diet develop a CFA to the diet over days and weeks (Harris et al. 1933; Richter 1943; Rozin 1976). However, the rapid decrease in intake of only CSG (fig. 1) and OGPT (fig. 2) is not consistent with this hypothesis. A reduction in protein or cell-wall digestion caused by blackbrush CTs also may decrease intake by decreasing fermentation rates in the rumen (Van Soest 1982), given that blackbrush is low in nitrogen and poorly digestible (Provenza et al. 1983a). In that case, we would expect a gradual decline in the intake of all foods by goats because of a general decline in the rate of passage of all plant particles from the rumen (Van Soest 1982). However, the rapid reduction in intake of only CSG (fig. 1) and OGPT (fig. 2) by goats is not consistent with this hypothesis. Other inconsistencies are that CSG is higher than OG in nitrogen (1.04\% vs. $0.74 \%)$ and more digestible in vitro in goat rumen fluid (48\% vs. $38 \%$ ), and that goats forced to consume CSG lose less weight than those that consume OG (Provenza et al. 1983a; Provenza and Malechek 1984). Thus, the primary effects of blackbrush CTs on the voluntary intake of CSG by goats apparently are not related to an inhibition of protein or carbohydrate digestion, and our data do not support the general hypothesis that mammalian herbivores reject tannin-containing plant parts because they adversely affect forage digestion (Rhoades and Cates 1976; Rhoades 1979; Swain 1979; Zucker 1983; Kumar and Singh 1984; Cooper and Owen-Smith 1985; Robbins et al. 1987a; Cooper et al. 1988). Rather, we argue that CTs from blackbrush CSG cause internal malaise because they are not bound to protein or cell-wall constituents.

\section{Twig Age and Learning}

Our results suggest that CTs play a major role in deterring goats from consuming blackbrush CSG by causing internal malaise. Furthermore, it is apparent that blackbrush OG is more palatable to goats than CSG because its CT content results in less internal malaise. Hence, blackbrush CSG must contain more CTs than OG, and/or CTs in CSG must differ structurally from those in OG. Currently, neither of these hypotheses has been tested, although both factors may play a role.

Using the protein-precipitation method of Hagerman and Butler (1978), an earlier study (Provenza and Malechek 1983) determined that blackbrush CSG contains 2.4 times the level of CTs in blackbrush OG. However, the amount of CT in OG is less than expected because of dilution by growth. We propose that much 
of the CT present in OG was not detected in these earlier studies because it was covalently bound to cell-wall constituents and hence not extracted. Support for this hypothesis comes from studies of plant anatomy and physiology. Condensed tannins are synthesized in the endoplasmic reticulum and then accumulate in cell vacuoles (Chafe and Durzan 1973; Bauer and Walkinshaw 1974; Parham and Kaustinen 1977; Mueller and Greenwood 1978; Stafford et al. 1987). The bark of woody plants, including blackbrush (F. D. Provenza, unpublished data), contains considerably more CTs than the wood (Herrick and Hergert 1976). As bark ages, cells outside the periderm die, causing a differentiation between the outer, nonliving bark and the inner, living bark (Esau 1977). The CTs in nonliving cells may then become localized in cell walls (Shen et al. 1986; Stafford 1988) and bond with cell-wall constituents such as pectins and cellulose (Zucker 1983). The formation of bonds between CTs and cell-wall polysaccharides may explain why a high proportion of CTs are insoluble in water and most organic solvents (Shen et al. 1986). This hypothesis is consistent with reports that incorporating strong tannin-binding substances such as gelatin, polyvinylpyrrolidone, and polyethylene glycol into diets can greatly reduce the negative effects of CTs (Barry 1985; Mehansho et al. 1985; Blytt et al. 1988) and with evidence that animals protect themselves against CTs by producing proline-rich salivary proteins that strongly bind with CTs (Mehansho et al. 1983, 1985; Robbins et al 1987b). On the basis of this hypothesis, we predict that CTs isolated from blackbrush OG will be as deterrent to goats as CTs isolated from blackbrush CSG, because CTs no longer bound with plant cell-wall material adversely affect goats.

In addition, CTs in OG may cause less internal malaise in goats than do CTs in CSG, because they are structurally different. Subtle changes in CT structure can result in large differences in herbivore preference for foods containing CTs (Clausen et al. 1990). The structure of CTs can vary with their location in the plant (Karchesy and Hemingway 1980) and the age of the plant part (Porter et al. 1985). Changes in CT structure may result from abiotic oxidations, epimerizations, depolymerization or polymerization, or condensations in plant tissues (Karchesy and Hemingway 1980).

The structure of CTs affects the rate and extent of CT depolymerization, which in turn may affect the strength of a CFA: the more rapid the rate of CT depolymerization in an animal's digestive system, the more rapid and aversive the consequences and the stronger the CFA (Provenza et al. 1990). In an acidic environment, the rate of procyanidin depolymerization for CTs containing C4-C8 interflavane bonds exceeds that for CTs containing C4-C6 bonds (Hemingway and McGraw 1983; Hemingway et al. 1983). Similarly, 2,3-cis isomers (epicatechin units) typical of blackbrush CSG cleave more readily than 2,3-trans isomers (catechin units), whereas doubly linked A-2-type procyanidins do not depolymerize noticeably even under harsh conditions (Jacques and Haslam 1974).

If this hypothesis is valid, CTs must depolymerize under conditions similar to those found in the digestive tract. Certain CTs depolymerize under such conditions. Procyanidins cleave at $30^{\circ} \mathrm{C}$ in $0.6 \mathrm{~N} \mathrm{HCl}$ (Fletcher et al. 1977). Furthermore, sugar residues from O-glycosylated procyanidins cannot be cleaved without also cleaving the interflavane bonds (Porter et al. 1985). Finally, several researchers have reported that ingestion of diets high in CTs can result in growth 
depression (Kratzer et al. 1975), high mortalities (Lindroth and Batzli 1984; Mehansho et al. 1987), deformities (Rostagno et al. 1973; Elkin et al. 1978), and increased levels of phenol-detoxifying enzymes (Freeland et al. 1985) that are best rationalized in terms of absorption of CT-depolymerization products. Hence, it is reasonable to assume that some CTs depolymerize, at least partially, in the digestive tract of herbivores such as goats and that both the rate and extent of depolymerization as well as the depolymerization products will depend heavily on CT structure.

\section{SUMMARY}

It has been hypothesized that herbivores instinctively avoid tannin-containing plant parts in response to the adverse effects of tannins on forage digestion. However, we found that goats learned to avoid condensed tannins (CTs) from blackbrush current season's growth by associating the flavor of foods containing CTs with aversive postingestive consequences. The aversive consequences experienced by goats apparently are not related to digestion inhibition and may depend on the structure of CTs and on how CTs are bound with other cell constituents. These observations suggest several areas of inquiry related to the interaction between CTs and herbivores. A better understanding of the physiological effects of CTs and how herbivores perceive these effects is essential to our knowledge of chemically mediated interactions between plants and mammalian herbivores. With few exceptions, the effects of food flavor have not been separated from those associated with postingestive consequences, even though our data show that postingestive consequences strongly influence palatability. We also need to know how herbivores learn which plant species to eat and which to avoid while foraging in areas that contain a variety of plant species and parts with different kinds and concentrations of CTs. Condensed tannins are pervasive in nature and can defend plants from herbivory, but since many important forages contain high levels of tannins, the presence or absence of tannins per se does not reliably indicate food quality. To predict the ability of a tannin-producing plant to deter herbivores requires a full understanding of how changes in CT structure and binding affect herbivores.

\section{ACKNOWLEDGMENTS}

We thank J. Garcia and two anonymous reviewers for comments on the manuscript.

This research was supported by a grant from the National Science Foundation (BSR-8614856). It is published with the approval of the Director, Utah Agricultural Experiment Station, Utah State University, Logan, Utah, as Journal Paper 3746.

LITERATURE CITED

Anderson, G. A., M. E. Mount, A. A. Vrins, and E. L. Zimeremer. 1983. Fatal acorn poisoning in a horse: pathologic findings and diagnostic considerations. J. Am. Vet. Med. Assoc. 182:1105-1111. 
Austin, P. J., L. A. Suchar, C. T. Robbins, and A. E. Hagerman. 1989. Tannin-binding proteins in the saliva of deer and their absence in the saliva of sheep and cattle. J. Chem. Ecol. 15:1335-1347.

Barker, L. M., M. R. Best, and M. Domjan, eds. 1977. Learning mechanisms in food selection. Baylor University Press, Waco, Tex.

Barry, T. N. 1985. The role of condensed tannins in the nutritional value of Lotus pedunculatus for sheep. III. Rates of body and wool growth. Br. J. Nutr. 54:211-217.

Bate-Smith, E. C., and C. R. Metcalf. 1957. Leucoanthocyanins. III. The nature and systematic distribution of tannins in dicotyledonous plants. J. Linn. Soc. Lond. Bot. 55:669-705.

Bauer, P. S., and C. S. Walkinshaw. 1974. Fine structure of tannin accumulations in callus cultures of Pinus elliotti (slash pine). Can. J. Bot. 52:615-619.

Berenbaum, M. 1985. Brementown revisited: interactions among allelochemicals in plants. Recent Adv. Phytochem. 19:139-170.

Bermudez-Rattoni, F., D. L. Forthman Quick, M. A. Sanchez, J. L. Perez, and J. Garcia. 1988. Odor and taste aversions conditioned in anesthetized rats. Behav. Neurosci. 102:726-732.

Bernays, E. A., G. Cooper Driver, and M. Bilgener. 1989. Herbivores and plant tannins. Adv. Ecol. Res. 19:263-302.

Bernays, E. A., and S. Woodhead. 1982. Plant phenols utilized as nutrients by a phytophagus insect. Science (Washington, D.C.) 216:201-203.

Blytt, H. J., T. K. Gusar, and L. G. Butler. 1988. Antinutritional effects and ecological significance of dietary condensed tannins may not be due to binding and inhibition of digestive enzymes. J. Chem. Ecol. 14:1455-1466.

Borison, H. L. 1986. Anatomy and physiology of the chemoreceptor trigger zone and area postrema. Pages 10-17 in C. J. Davis, G. V. Lake-Bakaar, and D. G. Grahame-Smith, eds. Nausea and vomiting: mechanisms and treatment. Springer, New York.

Bowns, J. E., and N. E. West. 1976. Blackbrush (Coleogyne ramosissima Torr.) on southwestern Utah rangelands. Utah Agric. Exp. Stn. Res. Rep. 27. Utah State University, Logan.

Boyd, E. M., K. Bereczky, and I. Godi. 1965. The acute toxicity of tannic acid administered intragastrically. Can. Med. Assoc. J. 92:1292-1297.

Braveman, N. S., and P. Bronstein, eds. 1985. Experimental assessments and clinical applications of conditioned food aversions. New York Academy of Sciences, New York.

Bryant, J. P., F. S. Chapin III, and D. R. Klein. 1983. Carbon/nutrient balance of boreal plants in relation to vertebrate herbivory. Oikos 40:357-368.

Buresova, O., and J. Bures. 1973. Cortical and subcortical components of the conditioned saccharin aversion. Physiol. \& Behav. 11:435-439.

Burritt, E. A., and F. D. Provenza. 1989. Food aversion learning: ability of lambs to distinguish safe from harmful foods. J. Anim. Sci. 67:1732-1739.

1990. Ability of lambs to learn with a delay between food ingestion and consequences given meals containing novel and familiar foods. Appl. Anim. Behav. Sci. (in press).

Butler, L. G., J. C. Rogler, H. Mehansho, and D. M. Carlson. 1986. Dietary effects of tannins. Pages 141-157 in V. Cody, J. B. Harborne, and E. Middleton, eds. Plant flavonoids in biology and medicine: biochemical, pharmacological, and structure-activity relationships. Liss, New York.

Camazine, S. 1983. Mushroom chemical defense: food aversion learning induced by hallucinogenic toxin, muscimol. J. Chem. Ecol. 9:1473-1481.

Chafe, S. C., and D. J. Durzan. 1973. Tannin inclusions in cell suspension culture of white spruce. Planta (Berl.) 113:251-262.

Chapman, R. F., and W. M. Blaney. 1979. How animals perceive secondary compounds. Pages 161-198 in G. A. Rosenthal and D. H. Janzen, eds. Herbivores: their interactions with secondary plant metabolites. Academic Press, New York.

Chapple, R. S., and J. J. Lynch. 1986. Behavioral factors modifying acceptance of supplementary foods by sheep. Res. Develop. Agric. 3:113-120.

Chapple, R. S., M. Wodzicka-Tomaszewska, and J. J. Lynch. 1987a. The learning behavior of sheep when introduced to wheat. I. Wheat acceptance by sheep and the effect of trough familiarity. Appl. Anim. Behav. Sci. 18:157-162. 
1987b. The learning behavior of sheep when introduced to wheat. II. Social transmission of wheat feeding and the role of the senses. Appl. Anim. Behav. Sci. 18:163-172.

Clausen, T. P., F. D. Provenza, E. A. Burritt, J. P. Bryant, and P. B. Reichardt. 1990. Ecological implications of condensed tannin structure: a case study. J. Chem. Ecol. 16:2381-2392.

Coley, P. D., J. P. Bryant, and F. S. Chapin III. 1985. Resource availability and plant antiherbivore defense. Science (Washington, D.C.) 230:895-899.

Cooper, S. M., and N. Owen-Smith. 1985. Condensed tannins deter feeding by browsing ruminants in a South African savanna. Oecologia (Berl.) 67:142-146.

Cooper, S. M., N. Owen-Smith, and J. P. Bryant. 1988. Foliage acceptability to browsing ruminants in relation to seasonal changes in the leaf chemistry of woody plants in a South African savanna. Oecologia (Berl.) 75:336-342.

Davis, C. J., R. K. Harding, R. A. Leslie, and P. L. R. Andrews. 1986. The organization of vomiting as a protective reflex: a commentary on the first day's discussion. Pages 65-75 in C. J. Davis, G. V. Lake-Bakaar, and D. G. Grahame-Smith, eds. Nausea and vomiting: mechanisms and treatment. Springer, New York.

Davis, J. L., and J. Bures. 1972. Disruption of saccharin-aversion learning in rats by cortical spreading depression in the CS-US interval. J. Comp. Physiol. Psychol. 80:398-402.

Divers, T. J., W. A. Crowell, J. R. Duncan, and R. H. Whitlock. 1982. Acute renal disorders in cattle: a retrospective study of 22 cases. J. Am. Vet. Med. Assoc. 181:694-699.

Dollahite, J. W., R. F. Pigeon, and B. J. Camp. 1962. The toxicity of gallic acid pyrogallol, tannic acid and Quercus havardi in the rabbit. Am. J. Vet. Res. 23:1264-1267.

Donnelly, E. D. 1954. Some factors that affect palatability in sericea lespedeza, L. cuneata. Agron. J. 46:96-97.

Dove, F. W. 1935. A study of individuality in the nutritive instincts and of the causes and effects of variations in the selection of food. Am. Nat. 69:469-544.

Driedger, A., and E. E. Hatfield. 1972. Influence of tannins on the nutritive value of soybean meal for ruminants. J. Anim. Sci. 34:465-468.

du Toit, J. T., F. D. Provenza, and A. S. Nastis. 1990. Conditioned food aversions: how sick must a ruminant get before it detects toxicity in food? Appl. Anim. Behav. Sci. (in press).

Elkin, R. G., W. R. Featherston, and J. C. Rogler. 1978. Investigations of leg abnormalities in chicks consuming high tannin sorghum grain diets. Poult. Sci. 57:757-762.

Esau, K. 1977. Anatomy of seed plants. Wiley, New York.

Feeny, P. 1976. Plant apparency and chemical defense. Recent Adv. Phytochem. 10:1-40.

Fletcher, A. C., L. J. Porter, E. Haslam, and R. K. Gupta. 1977. Plant proanthocyanidins. III. Conformational and configurational studies of natural procyanidins. J. Chem. Soc. Perkin Trans. 1:1628-1637.

Forthman Quick, D. 1984. Reduction of crop damage by olive baboons (Papio anubis): the feasibility of conditioned taste aversion. Ph.D. diss. University of California, Los Angeles.

Freeland, W. J., and D. H. Janzen. 1974. Strategies in herbivory by mammals: the role of plant secondary compounds. Am. Nat. 108:269-289.

Freeland, W. J., P. H. Calcott, and D. P. Geiss. 1985. Allelochemicals, minerals and herbivore population size. Biochem. Syst. Ecol. 13:195-206.

Gamzu, E., G. Vincent, and E. Boff. 1985. A pharmacological perspective of drugs used in establishing conditioned food aversions. Pages 231-249 in N. S. Braveman and P. Bronstein, eds. Experimental assessments and clinical applications of conditioned food aversions. New York Academy of Sciences, New York.

Garcia, J. 1989. Food for Tolman: cognition and cathexis in concert. Pages 45-85 in T. Archer and L. Nilsson, eds. Aversion, avoidance, and anxiety. Erlbaum, Hillsdale, N.J.

Garcia, J., and W. G. Hankins. 1975. The evolution of bitter and the acquisition of toxiphobia. Pages 39-45 in D. A. Denton and J. P. Coghlan, eds. Olfaction and taste V: proceedings of the fifth international symposium. Academic Press, New York.

1977. On the origin of food aversion paradigms. Pages 3-19 in L. Barker, M. Domjan, and M. Best, eds. Learning mechanisms in food selection. Baylor University Press, Waco, TX.

Garcia, J., and M. D. Holder. 1985. Time, space and value. Hum. Neurobiol. 4:81-89.

Garcia, J., W. G. Hankins, and J. D. Coil. 1977. Koalas, men, and other conditioned gastronomes. 
Pages 195-218 in N. W. Milgram, L. Krames, and T. M. Alloway, eds. Food aversion learning. Plenum, New York.

Garcia, J., P. A. Lasiter, F. Bermudez-Rattoni, and D. A. Deems. 1985. A general theory of aversion learning. Pages 8-21 in N. S. Braveman and P. Bronstein, eds. Experimental assessments and clinical applications of conditioned food aversions. New York Academy of Sciences, New York.

Grahame-Smith, D. G. 1986. The multiple causes of vomiting: is there a common mechanism? Pages 1-8 in C. J. Davis, G. V. Lake-Bakaar, and D. G. Grahame-Smith, eds. Nausea and vomiting: mechanisms and treatment. Springer, New York.

Hagerman, A. E., and L. G. Butler. 1978. Protein precipitation method for the quantitative determination of tannins. J. Agric. Food Chem. 26:809-812.

1980. Condensed tannin purification and characterization of tannin associated proteins. J. Agric. Food Chem. 28:947-952.

Hagerman, A. E., and K. M. Klucher. 1986. Tannin-protein interactions. Pages 67-76 in V. Cody, J. B. Harborne, and E. Middleton, eds. Plant flavonoids in biology and medicine: biochemical, pharmacological, and structure-activity relationships. Liss, New York.

Harris, L. J., J. Clay, F. J. Hargreaves, and A. Ward. 1933. Appetite and choice of diet. The ability of the vitamin $\mathrm{B}$ deficient rat to discriminate between diets containing and lacking the vitamin. Proc. R. Soc. Lond. B, Biol. Sci. 63:161-190.

Harrison, F. A., K. J. Hill, and J. L. Mangan. 1963. Absorption and excretion of lithium and magnesium in the sheep. Biochem. J. 89:99-100.

Hawkins, G. E. 1955. Consumption and digestibility of lespedeza sericea hay and alfalfa hay plus gallotannin. J. Dairy Sci. 38:237-243.

Hemingway, R. W., and G. W. McGraw. 1983. Kinetics of acid-catalyzed cleavage of procyanidins. J. Wood Chem. Technol. 3:421-435.

Hemingway, R. W., G. W. McGraw, J. J. Karchesy, L. Y. Foo, and L. J. Porter. 1983. Recent advances in the chemistry of condensed tannins. J. Appl. Polymer Sci. 37:967-977.

Herrick, F. W., and H. L. Hergert. 1976. Utilization of chemicals from wood: retrospect and prospect. Recent Adv. Phytochem. 11:443-515.

Jacques, D., and E. Haslam. 1974. Plant proanthocyanidins. II. Proanthocyanidin-A2 and its derivatives. J. Chem. Soc. Perkin Trans. 1:2663-2671.

Jones, W. T., R. B. Broadhursh, and J. W. Lyttleton. 1976. The condensed tannins of pasture legume species. Phytochemistry (Oxf.) 15:1407-1409.

Karchesy, J. J., and R. W. Hemingway. 1980. Loblolly pine bark polyflavanoids. J. Agric. Food Chem. 28:222-228.

Kratzer, F. H., V. L. Singleton, R. Kadirvel, and G. V. N. Rayudu. 1975. Characterization and growth-depressing activity for chickens of several natural phenolic materials. Poult. Sci. 54:2124-2127.

Kubo, I., and F. J. Hanke. 1985. Multifaceted chemically based resistance in plants. Recent Adv. Phytochem. 19:171-194.

Kufeld, R. C. 1973. Foods eaten by the Rocky Mountain elk. J. Range Manage. 26:106-113.

Kufeld, R. C., O. C. Wallmo, and C. Feddema. 1973. Foods of the Rocky Mountain mule deer. U.S. For. Serv. Res. Rep. RM-111. Rocky Mountain Forest and Range Experiment Station, Fort Collins, Colo.

Kumar, R., and M. Singh. 1984. Tannins: their adverse role in ruminant nutrition. J. Agric. Food Chem. 32:447-453.

Lett, B. T. 1985. The pain-like effect of gallamine and naloxone differs from sickness induced by lithium chloride. Behav. Neurosci. 99:145-150.

Lindroth, R. L. 1988. Adaptations of mammalian herbivores to plant chemical defenses. Pages 415-445 in K. C. Spencer, ed. Chemical mediation of coevolution. Academic Press, New York.

Lindroth, R. L., and G. O. Batzli. 1984. Plant phenolics as chemical defenses: effects of natural products on survival and growth of prairie voles. J. Chem. Ecol. 10:229-244.

Lowther, W. L., and T. N. Barry. 1985. Nutritional value of "grasslands maku" lotus grown on low fertility soils. Proc. N.Z. Soc. Anim. Prod. 45:125-127. 
McLeod, M. N. 1974. Plant tannins-their role in forage quality. Nutr. Abstr. Rev. 44:803-815.

Mehansho, H., A. Hagerman, S. Clements, L. Butler, J. Rogler, and D. M. Carlson. 1983. Modulation of proline-rich protein biosynthesis in rat parotid glands by sorghums with high tannin levels. Proc. Natl. Acad. Sci. USA 80:3948-3952.

Mehansho, H., J. Rogler, L. G. Butler, and D. M. Carlson. 1985. An unusual growth inhibiting effect of tannins on hamsters. Fed. Proc. 44:1860.

Mehansho, H., L. G. Butler, and D. M. Carlson. 1987. Dietary tannins and salivary proline-rich proteins: interactions, induction, and defense mechanisms. Annu. Rev. Nutr. 7:423-440.

Mitjavila, S., C. Lacombe, G. Carrera, and R. Derache. 1977. Tannic acid and oxidized tannic acid on the functional state of rat intestinal epithelium. J. Nutr. 107:2113-2121.

Mueller, W. C., and A. D. Greenwood. 1978. The ultrastructure of phenolic-storing cells fixed with caffeine. J. Exp. Bot. 29:757-764.

National Research Council. 1981. Nutrient requirements of goats: angora, dairy, and meat goats in temperate and tropical countries. National Academy Press, Washington, D.C.

Nunez-Hernandez, G., J. L. Holecheck, J. D. Wallace, M. L. Galyean, A. Tembo, R. Valdez, and M. Cardenas. 1989. Influence of native shrubs on nutritional status of goats: nitrogen retention. J. Range Manage. 42:228-232.

Olsen, J. D., and M. H. Ralphs. 1986. Feed aversion induced by intraruminal infusion with larkspur extract in cattle. Am. J. Vet. Res. 47:1829-1833.

Parham, R. A., and H. M. Kaustinen. 1977. On the site of tannin synthesis in plant cells. Bot. Gaz. 138:465-467.

Pelchat, M. L., H. J. Grill, R. Rozin, and J. Jacobs. 1983. Quality of acquired responses to tastes by Rattus norvegicus depends on type of associated discomfort. J. Comp. Psychol. 97:140-153.

Figeon, R. F., B. J. Camp, and J. W. Dollahite. 1962. Oral toxicity and polyhydroxyphenol moiety of tannin isolated from Quercus havardi (shin oak). Am. J. Vet. Res. 23:1268-1270.

Porter, L. J., L. Y. Foo, and R. H. Furneaux. 1985. Isolation of three naturally occurring O- $\beta$ glucopyranosides of procyanidin polymers. Phytochemistry (Oxf.) 24:567-569.

Prien, R. F., E. M. Caffey, and C. J. Klett. 1971. Lithium carbonate: a survey of the history and current status of lithium in treating mood disorders. Dis. Nerv. Syst. 32:521-531.

Provenza, F. D., and D. F. Balph. 1987. Diet learning by domestic ruminants: theory, evidence and practical implications. Appl. Anim. Behav. Sci. 18:211-232.

1988. The development of dietary choice in livestock on rangelands and its implications for management. J. Anim. Sci. 66:2356-2368.

1990. Applicability of five diet-selection models to various foraging challenges ruminants encounter. Pages 423-459 in R. N. Hughes, ed. Behavioral mechanisms of food selection. NATO ASI Ser. G: Ecol. Sci. Vol. 20. Springer, Heidelberg.

Provenza, F. D., and J. C. Malechek. 1983. Tannin allocation in blackbrush (Coleogyne ramosissima). Biochem. Syst. Ecol. 11:233-238.

1984. Diet selection by domestic goats in relation to blackbrush twig chemistry. J. Appl. Ecol. $21: 831-841$.

1986. A comparison of food selection and foraging behavior in juvenile and adult goats. Appl. Anim. Behav. Sci. 16:49-61.

Provenza, F. D., J. E. Bowns, P. J. Urness, J. C. Malechek, and J. E. Butcher. 1983a. Biological manipulation of blackbrush by goat browsing. J. Range Manage. 36:513-518.

Provenza, F. D., J. C. Malecheck, P. J. Urness, and J. E. Bowns. 1983b. Some factors affecting twig growth in blackbrush. J. Range Manage. 36:518-520.

Provenza, F. D., D. F. Balph, J. D. Olsen, D. D. Dwyer, M. H. Ralphs, and J. A. Pfister. 1988. Toward understanding the behavioral responses of livestock to poisonous plants. Pages 407-424 in L. F. James, M. H. Ralphs, and D. B. Nielsen, eds. The ecology and economic impact of poisonous plants on livestock production. Westview, Boulder, Colo.

Provenza, F. D., J. A. Pfister, and C. D. Cheney. 1990. Mechanisms of learning in diet selection with reference to phytotoxicosis in herbivores. J. Range Manage. (in press).

Reichardt, P. B., J. P. Bryant, T. P. Clausen, and G. Wieland. 1984. Defense of winter-dormant Alaska paper birch against snowshoe hares. Oecologia (Berl.) 65:58-69.

Reichardt, P., T. Clausen, and J. Bryant. 1987. Plant secondary metabolites as feeding deterrents to 
vertebrate herbivores. Pages 37-42 in F. D. Provenza, J. T. Flinders, and E. D. McArthur, comps. Proceedings-symposium on plant-herbivore interactions. U.S. For. Serv. Gen. Tech. Rep. INT-222. Intermountain Research Station, Ogden, Utah.

Rhoades, D. F. 1979. Evolution of plant chemical defense against herbivores. Pages 4-48 in G. A. Rosenthal and D. H. Janzen, eds. Herbivores: their interactions with secondary plant metabolites. Academic Press, New York.

Rhoades, D. F., and R. G. Cates. 1976. Toward a general theory of plant antiherbivore chemistry. Recent Adv. Phytochem. 10:168-213.

Richter, C. P. 1943. Total self-regulatory functions in animals and human beings. Harvey Lect. 38:63-103.

Riggs, R. A., P. J. Urness, and T. A. Hall. 1988. Diets and weight responses of spanish goats used to control gambel oak. Small-Ruminant Res. 1:259-271.

Riley, A. L., and D. L. Tuck. 1985. Conditioned taste aversions: a behavioral index of toxicity. Pages 272-292 in N. S. Braveman and P. Bronstein, eds. Experimental assessments and clinical applications of conditioned food aversions. New York Academy of Sciences, New York.

Robbins, C. T., T. A. Hanley, A. E. Hagerman, O. Hjeljord, D. L. Baker, C. C. Schwartz, and W. W. Martz. 1987a. Role of tannins in defending plants against ruminants: reduction in protein availability. Ecology 68:98-107.

Robbins, C. T., S. Mole, A. E. Hagerman, and T. A. Hanley. 1987b. Role of tannins in defending plants against ruminants: reduction in dry matter digestion? Ecology 68:1606-1615.

Roll, D. L., and J. C. Smith. 1972. Conditioned taste aversion in anesthetized rats. Pages 98-102 in M. E. P. Seligman and J. L. Hager, eds. Biological boundaries of learning. Appleton-Century-Crofts, New York.

Rostagno, H. S., J. C. Rogler, and W. R. Featherston. 1973. Studies on the nutritional value of sorghum grain with varying tannin content for chicks. II. Amino acid digestibility studies. Poult. Sci. 52:772-778.

Rozin, P. 1976. The selection of foods by rats, humans and other animals. Pages 21-76 in J. S. Rosenblatt, R. A. Hinde, E. Shaw, and C. Beer, eds. Advances in the study of behavior. Academic Press, New York.

Sandusky, G. E., C. J. Fosnaugh, J. B. Smith, and R. Mohan. 1977. Oak poisoning of cattle in Ohio. J. Am. Vet. Med. Assoc. 171:627-629.

Sell, D. R., W. M. Reed, C. L. Chrisman, and J. C. Rogler. 1985. Mucin excretion and morphology of the digestive tract as influenced by sorghum tannins. Nutr. Rep. Int. 31:1369-1374.

Shen, Z., E. Haslam, C. P. Falshaw, and M. J. Begley. 1986. Procyanidins and polyphenols of Larix gmelini bark. Phytochemistry (Oxf.) 25:2629-2635.

Shepherd, H. R. 1971. Effects of clipping on key browse species in southwestern Colorado. Colo. Div. Game, Fish Parks Tech. Publ. 28. Denver, Colo.

Spier, S. J., B. P. Smith, B. A. Seawright, B. B. Norman, S. R. Ostrowski, and M. N. Oliver. 1987. Oak toxicosis in cattle in northern California: clinical and pathological findings. J. Am. Vet. Med. Assoc. 191:958-964.

Stafford, H. A., 1988. Proanthocyanidins and the lignin connection. Phytochemistry (Oxf.) 27:1-6.

Stafford, H. A., H. H. Lester, and R. M. Weider. 1987. Histochemical assay of proanthocyanidin heterogeneity in cell cultures. Plant Sci. (Shannon) 52:99-104.

Swain, T. 1979. Tannins and lignin. Pages 657-681 in G. A. Rosenthal and D. H. Janzen, eds. Herbivores: their interaction with secondary plant metabolites. Academic Press, New York.

Thorhallsdottir, A. G., F. D. Provenza, and D. F. Balph. 1987. Food aversion learning in lambs with or without a mother: discrimination, novelty and persistence. Appl. Anim. Behav. Sci. 18:327-340.

$1990 a$. Ability of lambs to learn about novel foods while observing or participating with social models. Appl. Anim. Behav. Sci. 25:25-33.

$1990 \mathrm{~b}$. The role of the mother in the intake of harmful foods by lambs. Appl. Anim. Behav. Sci. 25:35-44.

1990c. Social influences on conditioned food aversions in sheep. Appl. Anim. Behav. Sci. 25:45-50.

Van Soest, P. J. 1982. Nutritional ecology of the ruminant. O \& B, Corvallis, Oreg. 
Wang, S. C. 1965. Emetic and antiemetic drugs. Pages 255-328 in W. S. Root and F. G. Hofmann, eds. Physiological pharmacology. Academic Press, New York.

Wilkins, H. L., R. P. Bates, P. R. Henson, I. L. Lindahl, and R. E. Davis. 1953. Tannin and palatability in sericea lespedeza, L. cuneata. Agron. J. 45:335-336.

Winer, B. V. 1971. Statistical principles in experimental design. McGraw-Hill, New York.

Zahorik, D. M., and K. A. Houpt. 1977. The concept of nutritional wisdom: applicability of laboratory learning models to large herbivores. Pages 45-67 in L. M. Barker, M. Best, and M. Domjan, eds. Learning mechanisms in food selection. Baylor University Press, Waco, Tex.

1981. Species differences in feeding strategies, food hazards, and the ability to learn food aversions. Pages 289-310 in A. C. Kamil and T. D. Sargent, eds. Foraging behavior. Garland, New York.

Zucker, W. V. 1983. Tannins: does structure determine function? An ecological perspective. Am. Nat. 121:335-365. 